\begin{tabular}{|c|c|c|}
\hline 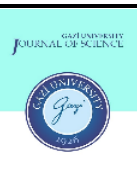 & $\begin{array}{c}\text { Gazi University } \\
\text { Journal of Science }\end{array}$ & 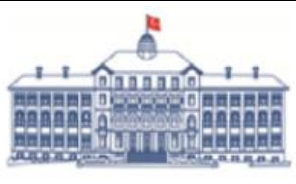 \\
\hline & http://dergipark.gov.tr/gujs & \\
\hline
\end{tabular}

\title{
Comparative Study of Symbolic Motifs of Peacock and Simurgh in Selected Historical Monuments of the Safavid Period in Ardabil and Isfahan Cities (Iran)
}

\author{
Roya ESMI ${ }^{1}$ (i) , Habib SHAHBAZI SHIRAN ${ }^{2, *}$ (iD) \\ ${ }^{I}$ PhD student in Archeology, University of Mohaghegh Ardabili, Faculty of Social Sciences, Department of Archeology, Ardabil, Iran \\ ${ }^{2}$ Associate Professor, University of Mohaghegh Ardabili, Faculty of Social Sciences, Department of Archeology, Ardabil, Iran
}

Highlights

- This paper examines the symbolic motifs (Simurgh and Peacock) in Safavid period monuments in Iran.

- The selected monuments in Ardabil and Isfahan cities are the target of study.

- Comparative interpretation is based on the location and number of motifs in the two cities.

\section{Article Info}

Received: 02 May 2020

Accepted: 19 Sep 2021

\section{Keywords}

Symbolic motifs

Simurgh

Peacock

Safavid period

\begin{abstract}
The symbolic motifs of birds in historical monuments are an embodiment of religious concepts and ancient myths and express the rich mystical content, human aspirations and desires through its historical period. Therefore, this study seeks to examine the commonalities or differences between the location, number and interpretations of bird motifs (Simurgh and Peacock) at the beginning and the end of the Safavid dynasty, in selected monuments of the cities of Ardabil (Sheikh Safi al-Din Ardabili's Khānegāh and the tomb of Sheikh Amin al-Din Jabrail) and Isfahan (Shah Mosque, Hasht Behesht Palace, Chahār Bāgh school and Emamzadeh Haroun-e-Velayat). In this study, field method and content and historical analysis of information sources and documents were used. The analysis showed that most of the Peacock and Simurgh motifs are found in the monuments of Ardabil, in the interior and exterior spaces, and in the selected monuments of Isfahan, mostly in the exterior spaces, facaded and entrance gates. The Peacock bird motifs in the monuments of Ardabil city, probably refers more to deep mysticism, perishing in God, spirituality and inner purity, but in the monuments of Isfahan city, the Peacock motifs often serves as a gatekeeper and guiding people toward heaven and repelling the devil. Also, Simurgh's motifs in the historical monuments of Ardabil city seem to be somewhat reminiscent of unity in plurality, a symbol of the essence of transcendence, perfect man and divinity; However, in the historical monuments of Isfahan, it often refers to the conflicting concepts of the human soul, which includes Ahura Mazda and Ahriman, and indicates man's attempt to overcome his own soul.
\end{abstract}

\section{INTRODUCTION}

Throughout the history of Iran, there has always been a very close connection between art and spiritual rites derived from religion. In addition, decorative motifs in Iranian-Islamic culture and art have a value beyond apparent beauty. Although this beauty is one of the main characteristics of Islamic art, but these motifs also have higher values, which are supreme mystical meaning of life. The glory of Islamic architecture often lies in its decorations. Types of Islamic motifs according to the source of inspiration and the theme of the motifs can be divided into human, animal, plant, geometric, objects and calligraphy groups. This collection of architectural decorations plays a key role in shaping and sustaining the goals of Islamic architecture [1].

The drawing of architectural decorations is taken from artists and masters of Islamic architecture in different historical periods, who have made a motif on historical monuments based on the desired concepts in each historical period. Leading artists of Islamic architecture showed cryptic manifestations of Iranian -Islamic 
wisdom and mysticism in their works of art [2]. The existence of beauty and creativity in the works of Muslim artists has not been the sole purpose of the artist. By referring to the available sources, including the verses of the Holy Quran, hadiths, mystical texts, literature, and ..., we can obtain acceptable evidence for understanding the symbolic meanings of some of the decorative motifs in Islamic Art. Peacock and Simurgh motifs are also among these symbolic motifs in Iranian art, which have been beautifully and masterfully worked on in decorating many Safavid sites in the cities of Isfahan and Ardabil [3]. Here, we evaluate the symbolic themes of these motifs.

From Carl Gustav Jung's point of view, a word or an image is considered a symbol when it involves something beyond its obvious and direct meaning. Religious systems, of course, have created a complex set of symbols because they believe in truth and supremacy [4]. Symbolic features have made it possible for human beings throughout history to use symbolic language and expression to express deep and multilayered meanings or supernatural concepts that are beyond the reach of the human mind [5]. The study of this dimension of Islamic art has been less discussed and scrutinized compared to its historical dimensions and the course of its technical evolution. Therefore, in this study, the concept of deep and hidden in the decoration of common animal motifs in selected monuments of Ardabil and Isfahan cities, which includes Peacocks and Simurgh, is discussed, so that while understanding the meanings, the possible differences of content should be found in the symbolic description of the mentioned patterns, according to the spatial distances [6].

The Peacock was not only used as a symbolic figure in Islamic art, but also in ancient times in Zoroastrianism, it was used as a sacred bird [3]. Tabari noted on Zoroastrian fire temples and temples that dates back to the third century AH, that near the Bukhara fire temple, there was a special place for keeping Peacocks, and due to the sanctity of the Peacocks, there was a place to keep the Peacocks [7, 8]. In ancient times, it was believed that the Peacock has gained eternal life because of drinking the water of life. In many works of the Sassanid period, the Peacock's design is located in decorations or on both sides of the tree of life [6]. For example, it can be seen the Peacock's design in the reliefs of the motif, fabrics or in the gypsum tablets of Ctesiphon of the Sassanid period [9]. The Peacock is one of the designs that has a significant presence in the decoration of mosques and religious places during the Safavid period. For example, the motifs of two Peacocks symmetrically on both sides of water of life's jar from which the tree of life has grown is one of the motifs that have been used to decorate the entrance porch of the Shah Mosque of Isfahan [10]. The reasons for the presence of this design on the forehead of the entrance porch of mosques, religious schools and Imamzadehs in the Safavid period, especially in Isfahan, in addition to the fact that the Peacock is considered a paradise bird, perhaps as mentioned in Attar's poems, was the gatekeeper and guide of the people to the mosque, and at the same time, it repels the devil and welcomes the believers. The Peacock, which in this period is a symbol of heaven, has appeared at the entrance of many buildings and monuments to welcomes people when entering these holy places [7, 9]. The Peacock has also been interpreted as a snake destroyer, so it is also considered a factor in the fertility of the earth. If the Peacock is impatient and restless before dawn, it is a sign of a storm [11]. Therefore, the use of the motif of the Peacock as a bird of paradise in most historical and religious places is due to the special nature of these creatures compared to others that distance itself from the material earth and fly up to the sky to evoke spirituality. In addition, it is often a symbol of goodness, blessing, and the fight against evil [3, 11].

Simurgh is one of the animal motifs with rich content, although it does not exist really in nature [12]; but, in the deep understanding of myth, it is important, and is often seen in the art of different periods in Iran, before and after Islam [3]. The motif of Simurgh before and after Islam has several meanings, and in the Islamic period, it was not only a symbol of the mystical mentor and the manifestation of the essence of truth, but also a symbol of the hidden soul. Therefore, understanding the meaning of this motif in Iranian art and its locations in the architectural decorations of the monuments is of special importance [9]. Simurgh is often a symbol of truth [12], and it can be said that the motif of the bird is the manifestation of man's long-standing desire to fly to the higher and spiritual worlds [10]. Simurgh has been a symbol of wisdom and healing in epic literature before Islam (Shahnameh) [3, 10]. Simurgh motifs in the Safavid period almost correspond to the descriptions given in literary and mythological sources. A big bird with numerous, long, twisted wings and tails, and a beak-like mouth is one of its characteristics, and it is more similar to the real 
physics of birds [11]. On the other hand, in Avesta, Simurgh is depicted as strong, large-bodied, with human characteristics $[12,13]$. Among the mystical meanings of Simurgh, we can mention the perfect man, the soul, the Holy Prophet (PBUH), the single intellect and the holy grace. In addition, sometimes an allegorical reference is made to the path and behavior of the devotees to reach the truth and the manifestation of the transcendent essence or the principle of unity in multiplicity, which Attar has shown its peak in the journey of the birds to the court of Simurgh (Malakout), in a very delicate way [11].

In the Safavid period, motifs of Peacock and Simurgh have been used extensively in monument architecture $[14,15]$. The first place and starting point of the Safavid dynasty was the city of Ardabil [16]. The Safavid dynasty lasted for 235 years from 1501 to 1736 AD [17-19]. The emergence of Sheikh Safi al-Din Ardabili in the city of Ardabil formed the origin of the history of the Safavid dynasty. The establishment of the Safavid government took place during the reign of Shah Ismail I, a descendant of Sheikh Safi [16]. The city of Ardabil, because it was the burial place of Sheikh Safi al-Din Ardabili and Shah Ismail I, was considered the spiritual capital of the Safavid kings and enjoyed special sanctity and respect among them [17, 19]. Therefore, the tomb of Sheikh Safi (burial place of Sheikh Safi al-Din Ardabili and Shah Ismail I) and his father Sheikh Amin al-Din Jabrail is considered as the most important monuments of Safavid history in Ardabil [16]. Towards the end of the Safavid dynasty, Shah Tahmasb chose the city of Qazvin as his capital [19].

Qazvin, due to its special geographical location, has been considered as one of the important strategic centers of Iran since the Sassanid dynasty. Nevertheless, one of the important points that was not considered by the Safavid kings in choosing the city of Qazvin (as the capital) was the problem of water shortage [16, 16]. The problem of water shortage in Qazvin on the one hand and the geographical and economic benefits that the city of Isfahan had on the other hand, caused the capital of the Safavid government to be moved from Qazvin to Isfahan [16]. The city of Isfahan had abundant water from the Zayandeh Rood River and was located in the center of Iran's geographical. It was also located along major trade routes, such as Damascus and Aleppo to the west and Samarkand and Bukhara to the east. Therefore, the city of Isfahan was known as the last capital of the Safavid dynasty [16, 19]. Finally, in a war between the Safavid government and the Afghans, Shah Sultan Hussein (the last Safavid king) surrendered and in 1736 AD, the Safavid dynasty fell in the city of Isfahan $[17,19]$.

The decorative motifs of Peacock and Simurgh have always been considered as a symbolic meaning for mystics and Sufis. Sufism and mysticism are also known as two prominent and dominant features in the common literature of the Safavid dynasty $[16,17]$. Therefore, Peacock and Simurgh always had a high conceptual and spiritual status in the decorative motifs of historical monuments in the Safavid period [14, 15]. According to the mentioned points, this study sought to investigate at the beginning and the end of the Safavid dynasty, what commonalities and differences in terms of location, number and interpretations of these motifs created in the architecture of the monuments. Therefore, the selected monuments of Ardabil (the place of the beginning of the Safavid dynasty) were selected as follows:

Sheikh Safi al-Din Ardabili's Khānegāh, belongs to the historical period of 735 AH to 1038 AH [20], is a famous collection of rich Islamic architecture, Islamic tile works, mosaics, stucco, epigraphy, wood carvings, silversmiths and goldsmiths, tong bori, muqarnas, and so on. The main parts of the Khānegāh include Daralhefaz, Ghandil-Khaneh or the prayer hall, Shah-Neshin, the tomb of Sheikh Safi (Gonbad Allah Allah), the tomb of Shah Ismail Safavid, Haram-Khane and Chini-Khaneh [5, 20, 21]. This collection has been registered by UNESCO as the twelfth cultural and historical monument of Iran with the number 1345 in the list of world and mystical cultural historical monuments [21, 22]. At first, this collection was nothing more than a simple house where Sheikh Safi al-Din Ishaq Ardabili, the great Sufi of the seventh century AH, lived and where he instructed his followers and disciples. His children developed this house after his death and it became an ensemble of religious - mausoleum monument [5, 21]. After the formation of the Safavid period and due to the religious movements that prevailed at that time, which were a mixture of Sufism and Shiism, the Safavid kings added new uses to this ensemble [23]; especially during the time of Shah Ismail, Shah Tahmasb, Shah Abbas I and Shah Abbas II, some monuments and buildings were 
added to them and the interior decorations of these monuments were reconsidered [22]. With the death of Sheikh Safi in $735 \mathrm{AH}$, children and disciples, his body was also buried in his private home [5, 23].

The tomb of Sheikh Amin al-Din Jabrail, the father of Sheikh Safi, is also one of the best examples of a large tomb in Iran, whose simplicity and harmony of its components and the extraordinary decoration of its interior surfaces make it one of the architectural masterpieces of the Safavid period. This tomb is located in the Kalkhoran area of Ardabil city, its construction was built in the first half of the 10th century AH and its construction was attributed to Shah Ismail I [24]. The tomb of Sheikh Amin al-Din has been built in the middle of a large area known as the Sheikh's Garden in a four-sided shape with bricks and has porch, and dome [25]. The wooden box is located in the middle of the tomb and the inner cover of the dome has unique plaster Muqarnas, one of the masterpieces of the Safavid period [5].

The entrance porch with two side arches is located on the north side of the monument and the depth of the porch is 2.30 meter. On the east and west sides of the portico, two Khajeneshin connected to it, measuring 3 by 3 meters, as well as two similar spaces in the southern part of the tomb, have been considered and have been the place of pilgrims, according to historians. Apart from the old tomb of Sheikh Amin al-Din Jabrail, there are four other small tombs in the Kalkhoran area, most of which lack the antiquity and importance of architecture, that belongs to the ancestors of the Safavids such as Mohammad Arabi, Firooz Shah Zarrin Kolah and Abolghasem Sayyid Hamza ibn Musa Kazem (AS), and is located in the east, west and south directions of the tomb. The designs and the motifs on the tomb of Sheikh Amin al-Din, like the collection of Sheikh Safi, include geometric, plant and animal structures (including Simurgh and Peacock) [24]. Also, the selected monuments of Isfahan (the place of the end of the Safavid dynasty) were selected as follows:

Shah Mosque is located on the southern front of Naqsh-e Jahan Square. This mosque has been built as a four-porch form with an area of about $12264 \mathrm{~m}^{2}$ and dimensions of approximately 130 by 100 meters in the style of congregational mosques (jama masjid) in Iran [26]. The mosque is a four-porch building in four main directions and includes the sections of portal and Jelokhan (forecourt), Shabestan, porches and 2 schools with courtyard and room. The courtyard of the mosque is about $50 \times 70$ meters long and wide. From the south doorway of the porch, you can enter the gonbadkhaneh (vault), which is the most beautiful and important part of the mosque [22]. This mosque was built by the order of Shah Abbas I Safavid with the support and supervision of the Safavid government in the middle of the south side of the newly established Naghsh Jahan square with the architecture of Master Ali Akbar Isfahani. Construction work on the mosque began in $1021 \mathrm{AH}$ and continued until $1040 \mathrm{AH}$ [1]. Shah Mosque is one of the masterpieces of architecture, tiling (Kashani) and carving of Iran in the 11th century AH and the last historical year seen in the mosque is $1077 \mathrm{AH}$, the last year of the reign of Shah Abbas II and $1078 \mathrm{AH}$, the first year of the reign of Shah Suleiman (Suleiman of Persia) [27]. The decoration of the mosque dates back to the reign of Shah Abbas and was completed during the reign of his successors, Shah Safi, Shah Abbas II and Shah Suleiman [8].

Hasht Behesht Palace was added to royal places during the reign of Shah Suleiman (1077-1105 AH), the son of Shah Abbas II. Among all the beautiful palaces and Kolah Farangi built next to Chahār Bāgh, only Hasht Behesht Palace remains, exterior of which has now been renovated [28]. The palace was built in the middle of a garden with an area of 85 acres, which is called the Nightingale Garden [25]. Hasht Behesht Palace, as it appears from the writings, is a place of tourism and entertainment and its corners (vicinity) have been built for entertainment and rest [29]. According to the plan of Hasht Behesht Palace, an octagonal foundation has been built based on the number of degrees and entrances to Behesht (Heaven), and it includes 4 two-floor porch and an octagonal hall [30]. The entrance of each is located in its corners and in the middle of it; there is an octagonal space that leads to four clerestories. In the canopy, the hozkhaneh with roof light and beautiful Muqarnas have been worked with a hexagonal Kashkul [26, 28].

The four sides of the palace are large and the other four sides are small. The two staircases are located on the east and west sides of the palace, leading to porches that have two pillars on the roof. Passing through these porches, you can enter the large octagonal hall. On the second floor, the roof of the middle porch hall is dome-shaped, and at the top, there is a dome with eight lattice-like vents. There are also smaller domes 
above the rooms on the second floor. The patterns on the tiles are very varied and include humans, animals, birds and plants [30].

The mosque-school of Chahār Bāgh in Isfahan is important in two dimensions of structure and decoration as one of the most important buildings of the era of Shah Sultan Hossein Safavid [28, 31]. The most precious collection of beautiful Safavid art and the last exquisite and valuable work created by the kings of this dynasty in the historical city of Isfahan is Chahār Bāgh School or Soltani School, also known as Madarshah School $[1,32]$. According to the monument's plan, the square shape of the courtyard and the main court, as well as the placement of four backyards in the twists and turns of the four sides of the main courtyard are quite recognizable.

The total area of the monument is about 90 in 95 meters $\left(8550 \mathrm{~m}^{2}\right)$ and the dimensions of the central courtyard or Sahn are about 60 in 65 meters $\left(3900 \mathrm{~m}^{2}\right)$ [33]. There are about 150 rooms in Chahār Bāgh School [34]. The exterior of the building, which overlooks the street, has a luxurious entrance and seventeen openings of a two-floor porch, behind each of the upper porches is a room, with latticed doors and windows; it connects the porches. The main entrance (frontal) of the school is located between two long piers that each of them is four meters wide. This historical school is located between Chahār Bāgh Street and Abbasi Caravanserai, which was built between 1116 and 1126 AH by the order of Shah Sultan Hussein and with his direct support and supervision, for teaching and educating students of religious sciences [32].

The historical monument of Imamzadeh Haruniyeh in Isfahan (tomb of Haroun-e-Velayat), whose tomb and tiled entrance (frontal) are the relics of the reign of Shah Ismail I and dates to $918 \mathrm{AH}$, is one of the holy places and major shrines in Isfahan that has a tomb, a shrine, a portico and a tiled dome and two courtyards to the north and west of the tomb. The oldest available date of construction is $918 \mathrm{AH}$ and most likely, it was built on the grave of one of the sons of Imam Musa Kazem [28, 35]. The bricklayer of this monument was apparently a person who vowed to meet his needs, to build the most beautiful tomb if his needs were met. When his dream came true, he built this magnificent tomb [35, 36]. Between the historic entrance (frontal) and the small courtyard of this tomb, a corridor is connected to the portico of the tomb on one side and to the courtyard on the other. In the middle of this corridor is located a trough (Sangab), which is engraved with an inscription with the following theme: "The endowment of the late Mohammad Hussein bin Agha Masih, was installed in 1261 AH". The beautiful entrance of the Imamzadeh of Haruniyeh, which is decorated with beautiful and delicate mosaic tiles with Islamic and Khatai motifs, is considered one of the most beautiful entrances (frontals) of the Imamzadegan [35].

\section{MATERIAL METHOD}

This is comparative study and the materials and findings of this study are provided in two methods: field method, and content and historical analysis of library resources, documents and second-hand sources. In the library method and the use of second-hand resources, the discussions about resources related to architectural decorations and Simurgh and Peacock motifs and analysis of research content on the interpretation of research motifs in selected monuments of Ardabil and Isfahan cities and its types were studied. In field studies, the method of direct observation, the researchers considered photography and image verification and the location of bird motifs. It should be noted that the monuments were considered to be located first in the cities of Ardabil and Isfahan; Secondly, they were built in the Safavid period and thirdly, they have Peacock and Simurgh motifs in the architectural decorations of their buildings. According to the mentioned conditions, from two different historical monuments in Ardabil, only two monuments of Sheikh Safi al-Din Ardabili's Khānegāh and Sheikh Amin al-Din Jabrail were selected. Also in Isfahan, the monuments of Shah Mosque, Hasht Behesht Palace, Chahār Bāgh School and Emamzadeh Haroun-eVelayat were selected. 


\section{THE RESEARCH FINDINGS}

\subsection{The Results of The Motifs' Facade and Location in The Selected Historical Monuments}

Peacock and Simurgh decorative motifs have a place in Iranian-Islamic culture and art beyond appearance beauty. Therefore, it can be acknowledged that "the purpose of using decorative designs and motifs in religious monuments was not only the beautify of these monuments, but also to pay more attention to the meaning hidden in it [37]; For example, in the ensemble of Sheikh Safi al-Din Ardabili, the artist has used the function of the spaces of the collection of symbolic images such as Arabesques, Khatais and polygamous stars and animals and birds such as Peacocks and Simurgh in the gates, porches, and ceilings to indicate the real world and to show the artists' awareness of the use of these motifs and their similarity with Quranic and mystical themes [11]. Therefore, it seems that there is a relationship between the location of these motifs and Quranic themes [2]. Tables 1 and 2 refer to the summary of the facade and location of the motifs separately based on the city (Ardabil and Isfahan) and selected monuments, which are based on photographs taken by the authors of this study or, in some cases, it has been compiled from authoritative scientific sources.

Table 1. Facade and location of Simurgh and Peacock motifs in selected monuments of Ardabil City

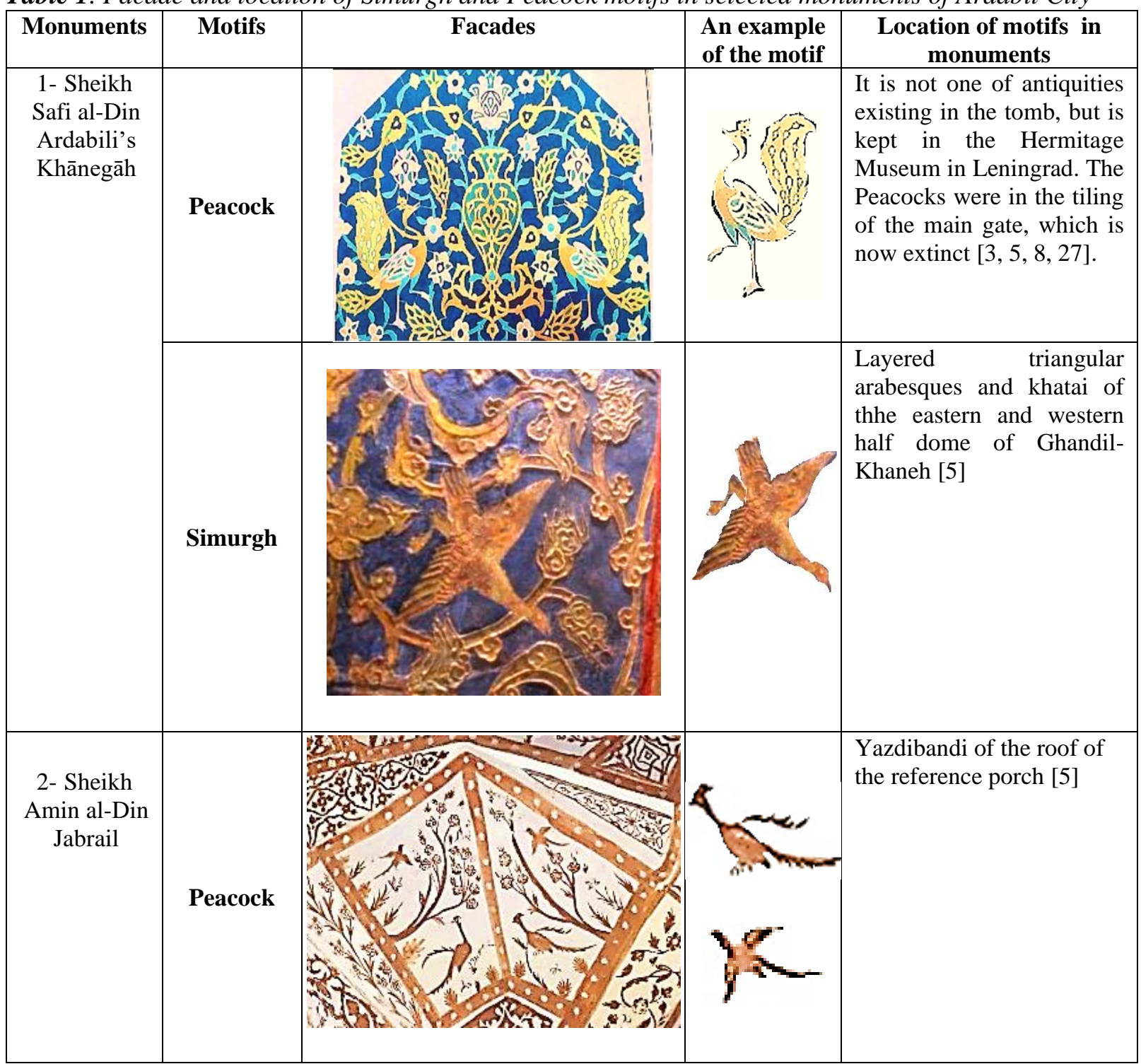




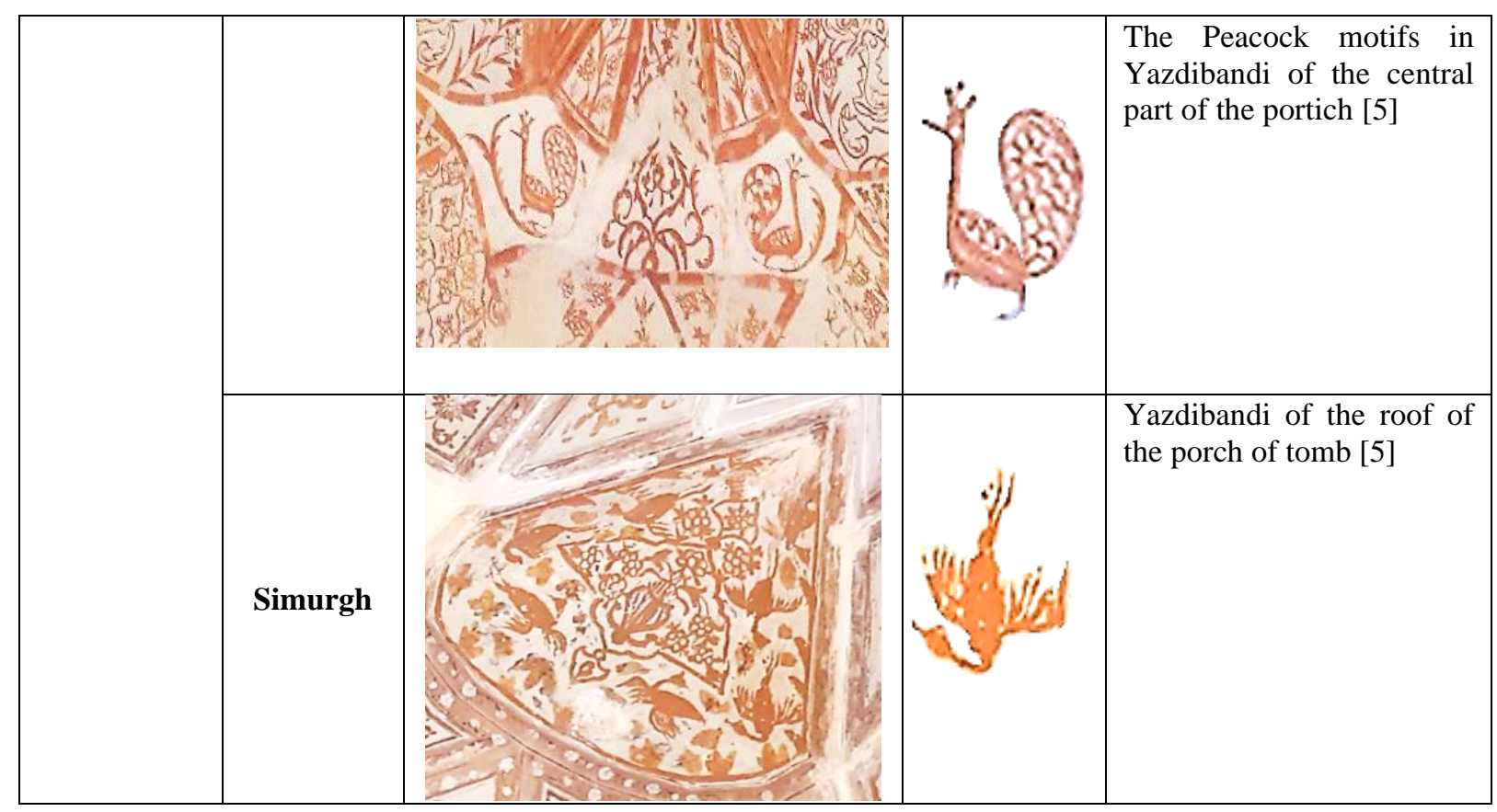

Table 2. Facade and location of Simurgh and Peacock motifs in selected monuments of Isfahan City

\begin{tabular}{|c|c|c|c|c|}
\hline Monuments & Motifs & Facades & $\begin{array}{c}\text { An example } \\
\text { of the motif }\end{array}$ & $\begin{array}{c}\text { Location of } \\
\text { motifs in } \\
\text { monuments }\end{array}$ \\
\hline \multirow[t]{2}{*}{$\begin{array}{l}\text { 1. Shah } \\
\text { Mosque }\end{array}$} & Peacock & 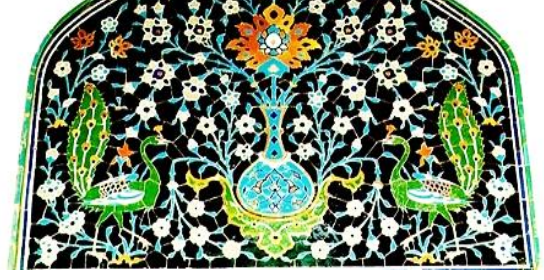 & & $\begin{array}{l}\text { In the decoration } \\
\text { of the frontal of } \\
\text { entrance gate }[2 \text {, } \\
13,14]\end{array}$ \\
\hline & Simurgh & -- & & -- \\
\hline \multirow[t]{2}{*}{$\begin{array}{l}\text { 2. Chahār Bāgh } \\
\text { School }\end{array}$} & Peacock & & 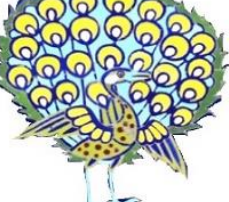 & $\begin{array}{l}\text { In the decoration } \\
\text { of the frontal of } \\
\text { entrance gate [10, } \\
\text { 13] }\end{array}$ \\
\hline & Simurgh & -- & & -- \\
\hline
\end{tabular}




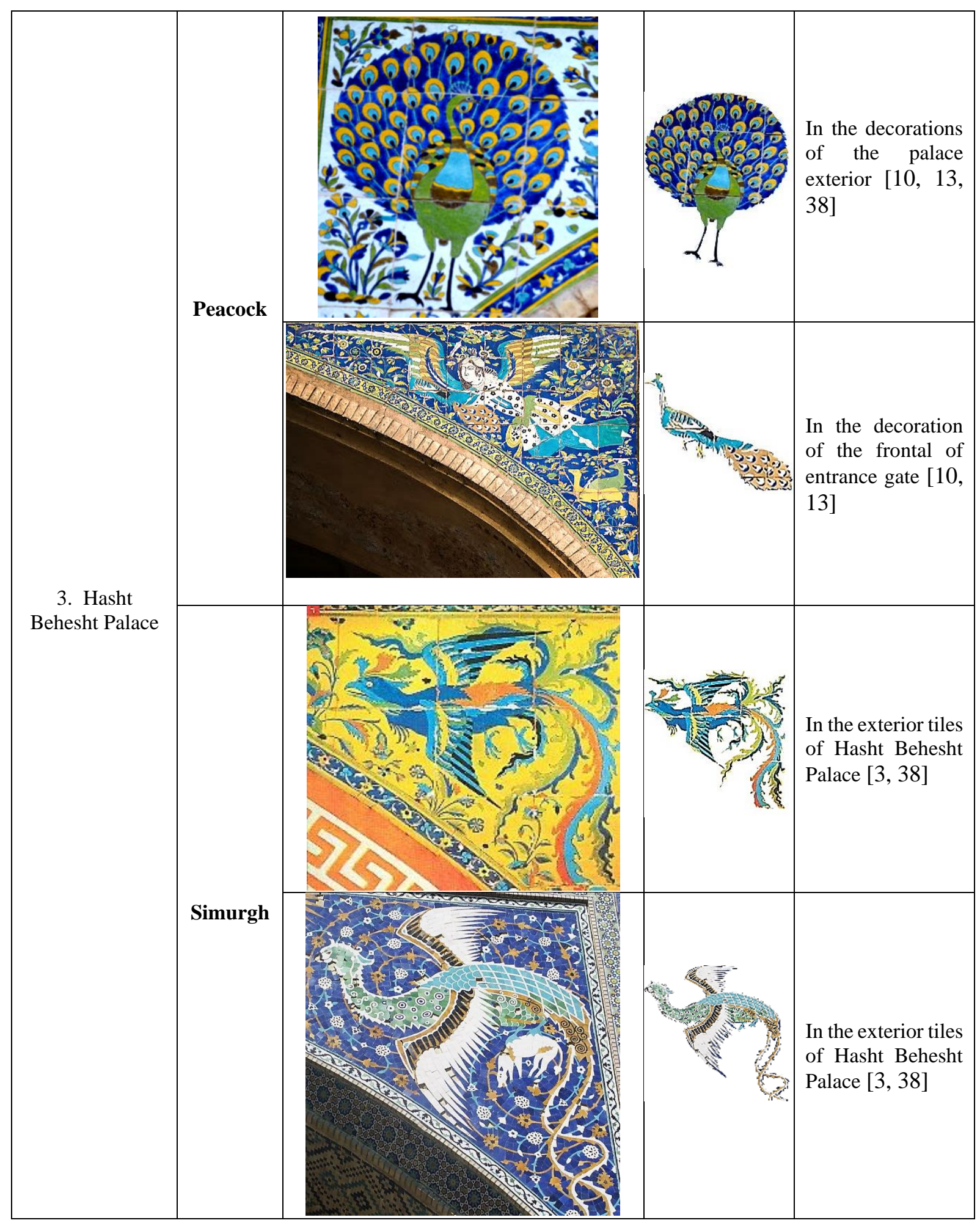




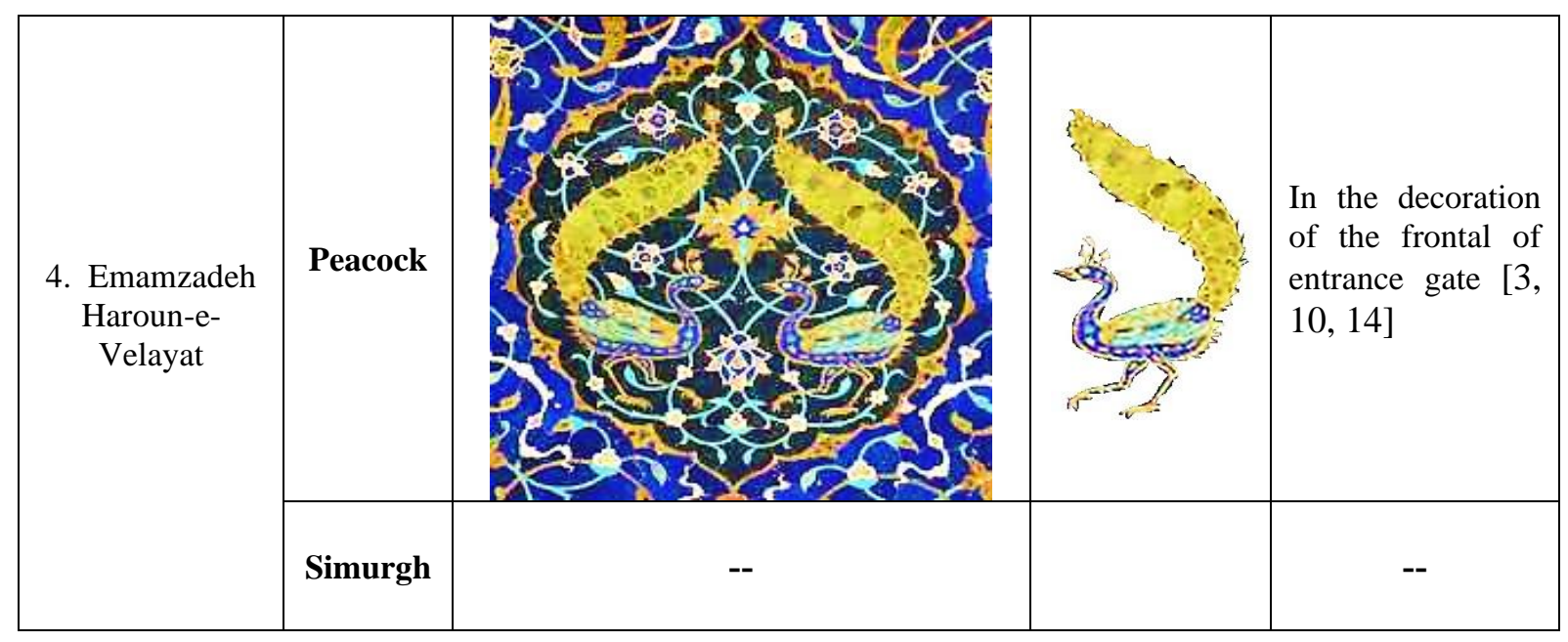

\subsection{Comparison of Peacock and Simurgh Motifs in Selected Historical Monuments}

For comparison of Peacock and Simurgh motifs, the diversity of spatial location and number of motifs in selected historical monuments were investigated. In Figures 1 and 2, based on the results of direct observation of study researchers and the background of the research, a comparison of the results obtained from the study of the diversity of locations of Peacock and Simurgh facades in two cities of Ardabil and Isfahan is presented. The results are as follows:

\subsection{Comparison of Location Diversity Between Peacock and Simurgh Motifs}

According to the findings (Figure 1), it seems that the location of Peacock motifs in the monuments of Ardabil city was mostly related to the places inside the monuments (roofs). However, in the selected monuments of Isfahan city, the location of the Peacock motifs was mostly related to the entrance and outside places of the monuments (walls and entrance gates). In addition, according to Figure 2, the location of Simurgh motifs in the monuments of Ardabil city has been mostly related to the places inside the monuments (walls and roofs). Nevertheless, in the selected monuments of Isfahan city, Simurgh motifs were mostly related to the entrance and exterior places of the monuments (walls and roofs).

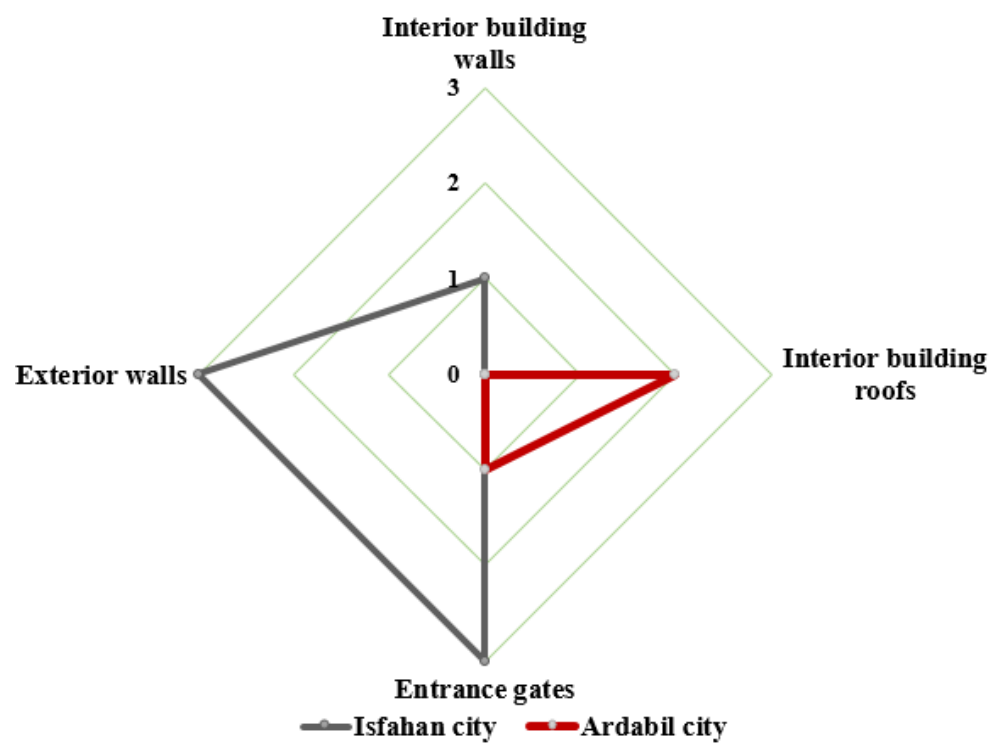

Figure 1. Comparison of diversity of Peacock' facades locations in two cities of Ardabil and Isfahan 


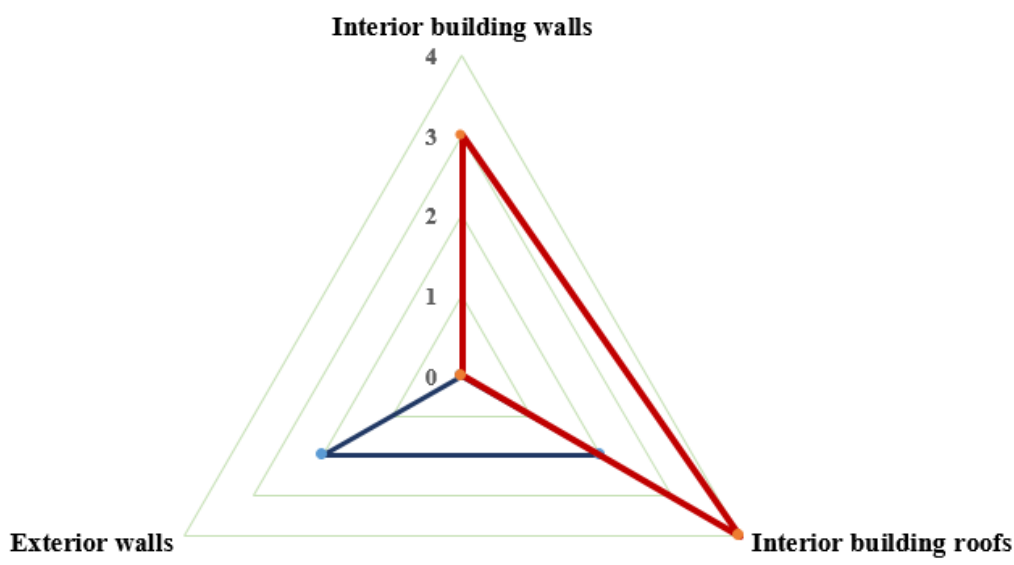

Figure 2. Comparison of diversity of Simurgh' facades locations in two cities of Ardabil and Isfahan

\subsection{Number of Peacock and Simurgh Motifs in Selected Monuments}

Comparing the total number of motifs between the selected monuments in Ardabil and Isfahan, considering that the number of monuments is not the same, it is not possible to compare. Therefore, here, only a report of the total number of bird motifs in the two cities is mentioned. According to Figure 4, in Ardabil, although the number of monuments under study ( 2 monuments) is less than the number of selected monuments in Isfahan (4 monuments), but the total number of Simurgh motifs used (28 motifs) is much more than the total number of motifs in selected monuments of Isfahan (4 motifs). However, the number of peacock motifs in the buildings of Ardabil (16 motifs) is less than the total motifs used in the monuments of Isfahan (20 motifs). Figure 3 shows the number of all motifs in the selected monuments. The details of the number of motifs in the selected monuments of both cities are presented separately in each monument in Table 3.

Table 3. Number of Peacock and Simurgh motifs in selected monuments of the two cities

\begin{tabular}{|c|c|c|c|}
\hline Cities & Monuments & Peacock & Simurgh \\
\hline \multirow{4}{*}{ Isfahan } & Shah Mosque & 6 & 0 \\
\cline { 2 - 4 } & Chahār Bāgh school & 4 & 0 \\
\cline { 2 - 4 } & Hasht Behesht Palace & 6 & 4 \\
\cline { 2 - 4 } & $\begin{array}{c}\text { Emamzadeh Haroun-e- } \\
\text { Velayat }\end{array}$ & 4 & 0 \\
\hline \multirow{4}{*}{ Ardabil } & Sum Sheikh Safi Al-din & 20 & 4 \\
\hline & Ardabili's Khānegāh & 4 & 12 \\
\cline { 2 - 4 } & $\begin{array}{c}\text { Tomb of Sheikh Amin al- } \\
\text { Din Jabrail }\end{array}$ & 12 & 16 \\
\hline
\end{tabular}



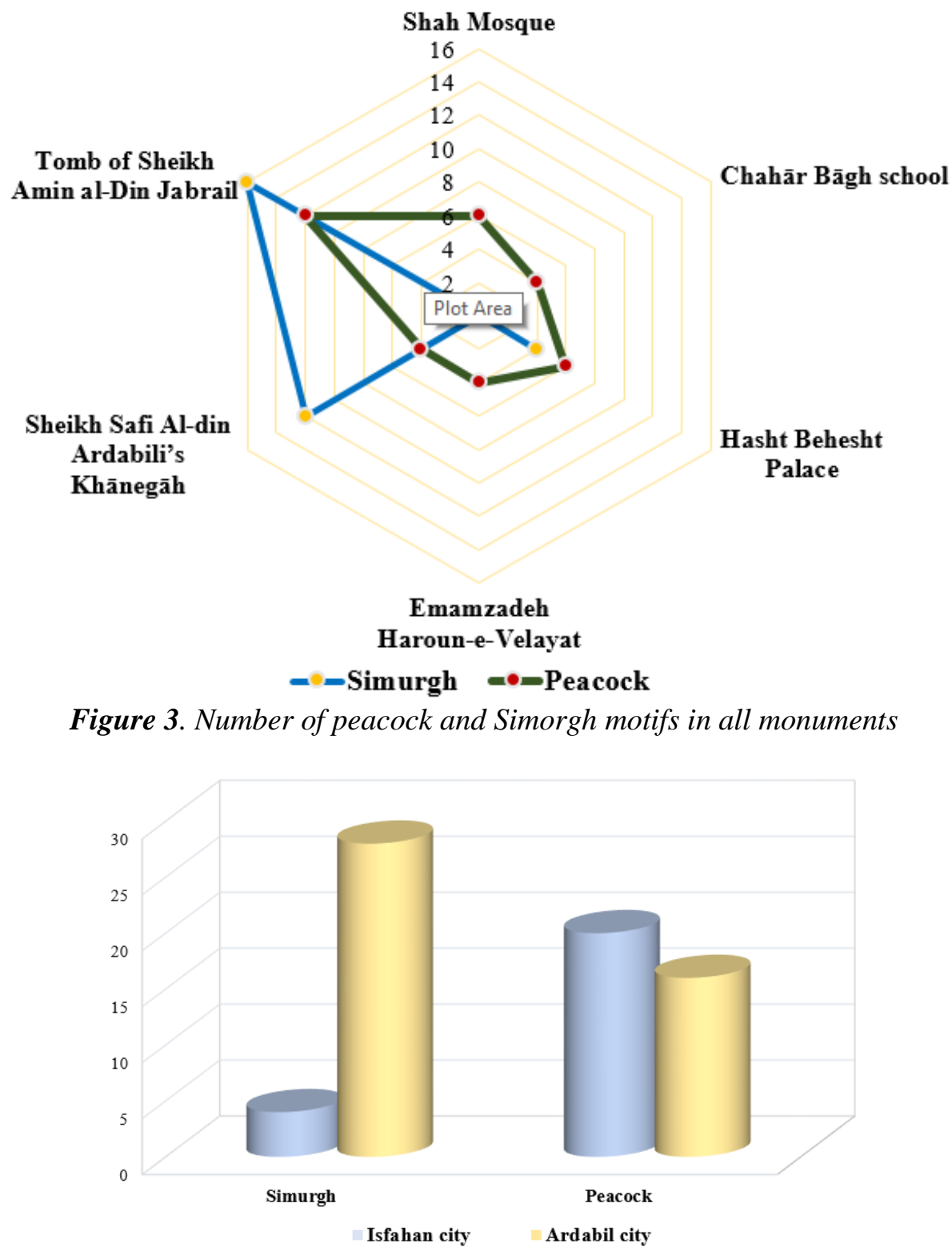

Figure 4. Number of Peacock and Simurgh motifs in the selected monuments

\subsection{Comparative Results of Symbolic Interpretations of Peacock and Simurgh Motifs in Selected Historical Monuments}

According to the results of differences in the location and the number of motifs in monuments and analysis of historical concepts related to Peacock and Simurgh motifs, the interpretation of symbolic motifs of these two birds in selected historical monuments is summarized and expressed based on cities in the Table 4 . 
Table 4. Symbolic interpretations of Peacock and Simurgh motifs in selected historical monuments

\begin{tabular}{|c|c|c|}
\hline $\begin{array}{l}\text { The selected } \\
\text { historical } \\
\text { monuments }\end{array}$ & Interpretation of Peacock motifs & Interpretation of Simurgh motifs \\
\hline $\begin{array}{l}\text { Ardabil city } \\
\text { (Sheikh Safi } \\
\text { al-Din } \\
\text { Ardabili's } \\
\text { Khānegāh and } \\
\text { the tomb of } \\
\text { Sheikh Amin } \\
\text { al-Din Jabrail) }\end{array}$ & $\begin{array}{l}\text { The motif of the Peacock bird in the historical } \\
\text { monuments of Ardabil city is often defined as a } \\
\text { symbol of purity, beauty, and dignity [11]. They } \\
\text { are also more reminiscent of unity and pluralism, } \\
\text { as if they are all in the rosary of the Supreme } \\
\text { Being, and they focus on supporting non-Muslims } \\
\text { and creating a sense of national unity in different } \\
\text { strata [14, 11]. In other words, it is believed that } \\
\text { the main purpose of showing birds such as Peacock } \\
\text { is to show the final stage of mysticism, which is to } \\
\text { reach the master and perish in God }[3,5,32,40] \text {. }\end{array}$ & $\begin{array}{l}\text { Considering the location of Simurgh motifs } \\
\text { in the historical monuments of Ardabil city, } \\
\text { their appropriateness so that they are flying } \\
\text { around center, seems to be somewhat } \\
\text { reminiscent of the phrase unity in plurality } \\
\text { and plurality in unity [5]. Therefore, it is } \\
\text { very likely that birds such as Simurgh are a } \\
\text { symbol of angels and their direction to the } \\
\text { center is a reference to the true and unique } \\
\text { world of God. As a conclusion, Simurgh } \\
\text { can be introduced as a symbol of the } \\
\text { essence of transcendence, perfect man, } \\
\text { divinity and unity in plurality [3,24]. }\end{array}$ \\
\hline $\begin{array}{l}\text { Isfahan city } \\
\text { (Shah } \\
\text { Mosque, } \\
\text { Hasht Behesht } \\
\text { Palace, Chahār } \\
\text { Bāgh school } \\
\text { and } \\
\text { Emamzadeh } \\
\text { Haroun-e- } \\
\text { Velayat) }\end{array}$ & $\begin{array}{l}\text { In Isfahan's historical monuments, considering the } \\
\text { location of the Peacock motifs and its shape and } \\
\text { form, in the interpretation of the Peacock, one can } \\
\text { perhaps point to the prominent and symbolic role } \\
\text { of guarding to prevent the entry of the devil. Given } \\
\text { the location of the Peacock's bird motifs and the } \\
\text { symmetrical shape of the two Peacocks at the main } \\
\text { gate, or the entrances to the monuments [28], the } \\
\text { best symbolic interpretation available to the bird, } \\
\text { its motifs can be interpreted as birds of paradise as } \\
\text { gatekeepers and guides to Heaven [38, } 2] \text {. In other } \\
\text { words, the Peacock is the repellent of the devil and } \\
\text { the guide of the believers }[7,8] \text {. For the symbolic } \\
\text { interpretation of the Peacock, the guardian and } \\
\text { guide of heaven, the repulsion of the devil and the } \\
\text { tree of life are some of the interpretations about the } \\
\text { motifs of the Peacock [6,11,24]. }\end{array}$ & $\begin{array}{l}\text { In most of the monuments in Isfahan, it } \\
\text { seems that Simurgh's physical } \\
\text { characteristics are similar to those of } \\
\text { Gabriel, one of the closest Islamic angels. } \\
\text { In fact, his role has been in connection with } \\
\text { the world of corruption and the mediator } \\
\text { between God and the prophets. However, } \\
\text { The motif of Simurgh, it was not only a } \\
\text { symbol of the mystical mentor and the } \\
\text { manifestation of the essence of truth, but } \\
\text { also a symbol of the hidden soul. Simurgh } \\
\text { is a symbol of truth, and it can be said that } \\
\text { the motif of the bird is the manifestation of } \\
\text { man's long-standing desire to fly to the } \\
\text { higher and spiritual worlds [10, 12]. Also, } \\
\text { Simurgh is a symbol of divinity, perfect } \\
\text { man, immortality and the essence of the } \\
\text { absolute unity in Islamic mysticism [11]. }\end{array}$ \\
\hline
\end{tabular}

\section{CONCLUSION}

This study sought to investigate the commonalities and differences created in the decorative motifs of peacock and Simorgh (location, number and interpretation) in the monuments in the cities of the beginning and end of the Safavid dynasty. It seems that the Peacock and Simurgh motifs in Ardabil and Isfahan cities in terms of the number, location of the motifs as well as the interpretation of the motifs, have similarities and significant differences. In terms of the location of the motifs, most of the motifs of Peacock and Simurgh in the selected monuments of Ardabil city are embedded in the interior and exterior spaces of the monument (such as the roofs and interior walls of the Chini-Khaneh, Ghandil-Khaneh, etc.); while in the selected monuments of Isfahan, most of the motifs, are engraved on the exterior and entrance spaces (entrance gates, rood and walls). For example, for the ensemble of Sheikh Safi al-Din Ardabili (selected monuments of Ardabil city), we can mention the presence of Simurgh motifs on the roof of the middle porches of Ghandil-Khaneh, the wall of Chini-khaneh and the eastern and western half-domes of GhandilKhaneh. We can also mention the existence of Peacock motifs on the roof of the portico, the central part of the interior of the monuments and the presence of Simurgh motifs in the southwestern chamber and the portico roof of the mausoleum on the inside of the monument. Meanwhile, for the selected buildings of Isfahan city, such as the Shah Mosque of Isfahan, we can mention the existence of Peacock motifs on the entrance porch. Also, for Chahār Bāgh School, the motifs of Peacock and Simurgh are engraved on the outer spaces or frntal entrance and gates. In Hasht Behesht Palace, Peacock motifs have been included in the decoration of the exterior of the palace and Simurgh motifs have been included in the exterior tiles of Hasht Behesht Palace. 
According to the findings, the highest number in the monuments of Ardabil, the total number of Simurgh and Peacock motifs were 28 and 16, respectively. Meanwhile, in the monuments of Isfahan, the total number of Simurgh and Peacock motifs was 4 and 20, respectively. In other words, in the monuments of Ardabil, most of the motifs were Simurgh and in the monuments of Isfahan, there were more Peacock motifs. It seems that the passage of time and the difference in geographical location have increased the use of Peacock motifs in historical monuments. Also, Peacock motifs are located on the portal of entrance gate in the monument of Imamzadeh Haruniyeh. The reason for the different location of the motifs in most of the mentioned monuments is probably related to the difference in the expected concepts of different artists in two different places with a significant spatial distance (two different cities). Also, the main reasons for the establishment of historical monuments in the Safavid period can effect the expected concepts of Peacocks and Simurgh of those monuments [27]. Therefore, it is obvious that this difference in the location of the motifs on the interpretations obtained from the motifs can make a difference.

The motif of the Peacock bird in the historical monuments of Ardabil city is often more inclined to mysticism and inner purity of human content, and is more reminiscent of unity and plurality, as if they are all in the glorification of God [30]; and perishing in God is the main purpose of embedding Peacock motifs [5]. Therefore, the use of the motifs of the Peacock is considered as a heaven bird that distances itself from the material earth and by flying to the sky $[6,10]$, evokes ascension and spirituality, and it is often a symbol of goodness and blessing and the fight against evil [11]. But in historical monuments of Isfahan, considering the location of the Peacock motifs, their shape and number, in the interpretation of the Peacock, it may be possible to emphasize the prominent and symbolic role of guarding to prevent the entrance of the devil (mosque and paradise are places where the devil has no place) [10]. The Peacock is interpreted as a bird of paradise that has been introduced as the gatekeeper and guide of the people to heaven. In other words, the Peacock is the repellent of the devil and the guide of the believers [7, 8]. Also, because motifs of the Peacock are often embedded with the tree of life, which is considered to be the source of the blessings and sustenance of the heavenly beings (believers) [11, 24]. There are some differences between the selected historical monuments of Ardabil and Isfahan in connection with Simurgh motifs. Considering the location of Simurgh motifs in the historical monuments of Ardabil city, their appropriateness so that they are flying around center, seems to be somewhat reminiscent of the phrase unity in plurality and plurality in unity. Therefore, in general, Simurgh can be introduced as symbol of the essence of transcendence, perfect man, divinity and unity in plurality $[8,24]$.

\section{CONFLICTS OF INTEREST}

No conflict of interest was declared by the authors.

\section{REFERENCES}

[1] Yazdani, M., Safdari, M., Tarakh. M. R., "The place of Islamic teachings in Safavid architectural decorations", The Ninth Symposium on Advances in Science and Technology, Mashhad city (Iran), 113, (2014).

[2] Sadeghinia, S., Poozesh, S., "An Interpretive and Symbolic Study of the Role of the Peacock in Iranian Art”, Journal of Dramatic Literature and Visual Arts, 1(2): 53-62, (2015).

[3] Rahimi, F., "Symbolic Interpretation of Peacock and Simurgh Patterns in Isfahan Buildings of the Safavid Era", Second National Conference on Urban Planning, Architecture, Civil Engineering, Environment, Lorestan, Payashahr Engineers Group (Iran), 1-11, (2017).

[4] Saremi Nia, D., "A Look at the History of Architecture and Wall Paintings (Pirnia House in Nain City)", Art Month Book Monthly, 97: 60-65, (2006). 
[5] Rajabi Asl, M., "Structural adaptation and analysis of the designs and architectural arrays of the shrines of Sheikh Amin al-Din and Sheikh Safi al-Din in Ardabil", Master Thesis in Handicrafts, Traditional Arts Research Orientation. Faculty of Art, Soura Honar University, Iran, (2016).

[6] Kang, K., “The Peacock”, Symbols and Sandplay Therapy, 4(1): 35-43, (2013).

[7] Khazaei, M., "Interpretation of symbolic motifs of peacock and Simurgh in Safavid era buildings", Journal of Visual Arts, 26: 24-27, (2017).

[8] Kaur, R., "Peacock Motif in Phulkari: A Comprehensive Analysis", History Reviews of New Books, 242-253, (2016).

[9] Rahmani, F., Hesami, V., "Study of Simurgh's Role in Iranian Art, The Third National Conference on Iranian Archeology", Tehran, 1169-1181, (2017).

[10] Hosseini, S. H., Qaraati, E., Pournadari. H., "Artistic effects in tiling decorations of Khan Shiraz School”, Journal of Fine Arts - Visual Arts, 23(3): 53-64, (2018).

[11] Jafarzadeh, B., "Investigating the relationship between Sheikh Safi's collection of murals and Quranic themes", Master Thesis in Painting, Faculty of Arts, Shahed University, Iran, (2017).

[12] Zia Sheikh, S., "Persian Allegory of Chinoiserie Motifs-Dragon and Phoenix or Simurgh", International Journal of Multidisciplinary and Current Research, 5: 939-949, (2017).

[13] Dastgheib, N., Zafarmand, S.J., "Comparative study of bird motifs in Iranian pottery of the Abbasid period and Chinese pottery (related to the 9th century AD)", Journal of Negareh, 38: 107-117, (2016).

[14] Davazdah Emami, M., Zakariaee, I., "The symbol of the Peacock and its media role in Shiite architecture with emphasis on the mosques of the Safavid era of Isfahan", International Congress of Culture and Religious Thought, Qom city (Iran): Cultural Engineering Leadership Center of Bushehr Public Culture Council, 1-19, (2014).

[15] Alipour Nakhi, A., Karami, F., "Using Decorations in Architecture of Religious Constructions, Safavid Era, Isfahan (Divine Reflection or Artistic View)”, The Social Sciences, 11: 6604-6616, (2016).

[16] Khajegir, A., Afroogh, M., Fahim, A., "The Art of Islamic Architecture during the Safavid Period and the Introduction of the Teachings of Islam", Journal of Fine Arts, 1(3): 37-42, (2018).

[17] Sefatgol, M., "Rethinking the Safavid Iran (907-1148/1501-1736): Cultural and political identity of Iranian society during the Safavid period", Journal of Asian and African Studies, 72: 5-16, (2006).

[18] Jamaati-e-Somarin, B., Jamaati-e-Somarin, R., "Tomb of Sheikh Sfyaldyn Ardabil, Iran Eleventh World Heritage", Australian Journal of Basic and Applied Sciences, 5(8): 320-330, (2011).

[19] Savory, R., "Iran under the Safavids 1st Edition. Cambridge University Press", 1st edition, United Kingdom, 28, (2007).

[20] Shahbazi Shiran, H., Mammadova, I., "Archaeology, Art and Architecture "Chini Khaneh" and "Haram Khana", Journal of Multidisciplinary Engineering Science and Technology (JMEST), 1(5): 126-134, (2014).

[21] Esmi, R., Shahbazi Shiran, H., "Heritage Tourism Boom: Tourists' Tendency to Revisit Sheikh Safi Al-Din Ardabili Collection", Journal of Organizational Behavior Research, 4(2): 1-14, (2019). 
[22] Yosefi, H., Alizadeh, S., Tavousi, M., "Reconsidering the Architecture of Shaikh Safi al-Din Ardabili's Shrine: New Findings in Archeological Excavations at Jannat Sara Site", Humanities, 20(1): 49-67, (2013).

[23] Raees Zadeh, S., "Symbolic values in the designs of Sheikh Safi's collection", Master Thesis in Art Research, Faculty of Art and Architecture, Islamic Azad University, Central Tehran Branch, Iran, (2010).

[24] Dastgheib, N., Zafarmand, S.J., "Comparative study of bird motifs in Iranian pottery of the Abbasid period and Chinese pottery (related to the 9th century AD)", Journal of Negareh, 38: 107-117, (2016).

[25] Alemi, M., "Safavid Royal Gardens and Their Urban Relationships, A Survey of Persian Art, from Prehistoric Times to the Present, Islamic Period: From the End of the Sasanian Empire to the Present", Costa Mesa, Calif. Mazda Publishers, (2005).

[26] Pirnia, M., "Introduction to Islamic Architecture of Iran", Tehran: Soroush Danesh Publications, (2005)

[27] Blake, S. P., "Half the world: the social architecture of Safavid Isfahan", 1590-1722, Costa Mesa, Mazda Pub, (1999).

[28] Babaie, S., "Isfahan and its palaces: statecraft, Shi'ism and the architecture of conviviality in early modern Iran", Edinburgh, Edinburgh University Press, (2008).

[29] Dehmashgi, J., Janzadeh, J., “Art Effects in Isfahan”, Tehran: Janzadeh Publications, Iran, (1987).

[30] Ghasemi, S., "A comparative study was carried out and the paradise of Hasht Behesht Palace was paved with Safavid carpets (Case study: carpets of the Metropolitan Museum of Art)", Master Thesis in Islamic Archeology, University of Sistan and Baluchestan, Iran, (2015).

[31] Aghadavoudi, M., Zakariaee Kermani, I., Attari, A., "The typology of the inscriptions of the mosqueschool of Chahār Bāgh in Isfahan with emphasis on structural features", Journal of Art Research, 8(15): 71-85, (2018).

[32] Seyedin Nia, M., "Deciphering signs in architecture and decorations related to Imam Mosque of Isfahan", Master Thesis in Production Orientation, Tehran: Faculty of Radio and Television of the Islamic Republic of Iran, (2008).

[33] Khajeh Ahmad Atari, A., Aghadawoodi, M. Taghvinejad, B., "Implementation and analysis of the architectural structure and decorations of the two schools of Madrasa - Chahār Bāgh and Aligholi Agha", Iranology Studies, 8(1): 17-36, (2018).

[34] Keshavarzi, M. T., "Schools of Isfahan in the Safavid period", The study of the history and civilization of Iran and Islam, 1(2): 65-82, (2016).

[35] Godar, A., "Works of Iran, translated by Abolhassan Sarvghd Moghaddam", Volume 4, Second Edition, Mashhad: Astan Quds Razavi Printing and Publishing Institute, Iran, (1992).

[36] Makkinijad, M., "History of Iranian Art in the Islamic Period: Architectural Decorations", 1st Edition, Tehran: Samat Publications, (2008).

[37] Shayesteh Far, M., Gol Moghanizadeh Asl, M., "Inscriptions on the exterior of the tomb of SheikhSafi al-Din Ardabili”, Journal of Social Sciences and Humanities, Shiraz University, 19(1): 83-103, (2002). 
[38] Fallah Azizi, A., Shokrpour, S., "Comparative study of seven-color tiles of Hasht Behesht Palace in Isfahan with seven-color tiles of Ibrahim Khan Zahir al-Dawlah Bath in Kerman", Iranian Journal of Archeology, 6(2): 76-95, (2016). 